Logos Universality Mentality Education Novelty, Section: LAW

ISSN: $2284-5968$ (print), ISSN: $2284-5968$

(electronic)

Covered in: CEEOL, Index Copernicus, Ideas

RePeC, EconPapers, Socionet

\title{
THE PLACE AND THE ROLE OF THE PROSECUTOR IN THE CRIMINAL TRIAL ACCORDING TO THE NEW CODE OF CRIMINAL PROCEDURE \\ Dănuţ NEACŞU \\ Luminiţa SIMA
}

Logos Universality Mentality Education Novelty, Section:

LAW, 2014, Year III, Issue 1, pp: 39-46

Published by:
Lumen Publishing House
On behalf of:
Lumen Research Center in Social and Humanistic Sciences




\title{
The Place and the Role of the Prosecutor in the Criminal Trial according to the New Code of Criminal Procedure
}

\author{
Dănuț NEACŞU ${ }^{1}$ \\ Luminiţa SIMA ${ }^{2}$
}

\begin{abstract}
The paper outlines and critically approaches the changes in the new Code of Criminal Procedure with regards to the functional competence of the prosecutor and the court after the introduction in the criminal trial of some new principles such as the principle of separation of judicial functions, of opportunity in the exercise of a criminal action, of the right to a fair trial within a reasonable time, of the diminished exercise of the active role of the court and after the introduction in the criminal trial of the adversarial type elements. The changes with regards to the competence of the prosecutor emerge from the modifications of the basic principles of the criminal trial, which, along with the classical ones are meant to provide Romania with a new model of criminal proceedings in accordance with: the Romanian Constitution, the founding treaties of the European Union, the European Convention for the Protection of Human Rights and Fundamental Freedoms, of all the other European Union regulations along with covenants and treaties on fundamental human rights to which Romania is a member.

We refer to the principle of the separation of judicial functions in the criminal trial (art. 3 of the new Code of Criminal Procedure); the opportunity in the exercise of the criminal action [art. 7 paragraph. (2) of the new Code of Criminal Procedure); the right to a fair trial within a reasonable time (Art. 8 of the new Code of Criminal Procedure); the right to liberty and security (Article 9 of the new Code of Criminal Procedure); ne bis in idem (art. 6 of the new Code of Criminal Procedure); and the loyalty in obtaining evidence (art. 101 of the new Code of Criminal Procedure).
\end{abstract}

\section{Keywords:}

New Code of Criminal Procedure, Principle of Separation of Judicial Functions, Rights and Freedoms, Criminal Trial.

\footnotetext{
1 Lecturer, $\mathrm{PhD}$. at "Andrei Saguna" University of Constanta, Romania, danut.neacsu@yahoo.com.

2 Graduate student, Ovidius University, Constanta, Romania, luminita.sima38@yahoo.com.
}

Neacsu, D., Sima, L. (2014). The Place and the Role of the Prosecutor in the Criminal Trial according to the New Code of Criminal Procedure. Logos Universality Mentality Education Novelty, Section: LAW, Year III, Issue 1, 2014, pp. 39-46 


\section{Introduction}

One of the important novelties of the New Code of Criminal Procedure refers to the regulation of place and the role of the prosecutor within the new model of criminal trial.

The novelties referring to this place and role of the prosecutor emerge from setting the criminal trial on new bases which, next to the classical ones, were conceived to offer to Romania a new model of criminal trial according to the stipulations of the Constitution (Law no. 135/2010), of the constitutive treaties of the European Union, of the European Convention over the Fundamental Rights and Freedoms of an individual (The Convention for defending the human rights and the fundamental freedoms, concluded in Rome on the $4^{\text {th }}$ of November 1950 was ratified through the Law no. 30/ 1994), of the other regulations of the European Union, as well as with the pacts and the treaties regarding the fundamental rights of the individual to which Romania is part of.

The European Convention for defending the human rights and the fundamental freedom has a content and a more nuanced language referring to the role of the prosecutor within the protection of individual freedom, meaning that by means of the content of art. 5 para. 3, it let to the member states the possibility of assigning to the prosecutor some exact tasks regarding the individual freedom, and not only the general ones for the function of prosecutor, these being the principle of lawfulness and the presumption of guilt.

The substantial modifications, from the New Code of Criminal Procedure, first take into account the principle of separation of the judicial functions within the criminal trial (art. 3 The New Code of Cr. Pr.); of opportunity in the exercise of a criminal action (art. 7 para. (2), The N. C. Cr. Pr.); of the right to a fair trial within a reasonable time (art. 8 The New C. Of Cr. Pr.); of the right to freedom and safety (art. 9 The New C. Of Cr. Pr.); ne bis in idem (art. 6 The New C. Of Cr. Pr.) and the one of loyalty in obtaining the evidences (art. 101 The New C. Of Cr. Pr.) (Law no. 135/2010 regarding the New Code of Criminal Procedure, published in the Official Monitor no. 486 from the $15^{\text {th }}$ of July 2010)

\section{The Principle of separation of judicial functions within the criminal trial}

The principle of separation of judicial functions within the criminal trial stipulated in art. 3 The New Code of Criminal Procedure settled at the basis of the criminal trial, immediately after the principle of lawfulness, was conceived to arrange and to discipline the entire chain of criminal procedure institutions, 
The Place and the Role of the Prosecutor in the Criminal Trial according to (...)

Dănuț NEACŞU, Luminița SIMA

so that to ensure the efficiency guarantees, the impartiality and fairness of the criminal trial.

The place of the matter is art. 3 The New Code of Cr. Pr., with all the 7 paragraphs which can be divided into 2 parts: in a first part, the paragraph exposes and defines the four judicial functions which are exercised within the criminal trial, establishes the functional authorities of the criminal body which exercises each judicial function and the aim of each judicial function, as follows:

The function of criminal prosecution which existed within the old Code, without being defined, exercised, according to art. 3 para. 4) The New Code of Cr. Pr., by the prosecutor and the criminal prosecution bodies which collect the necessary evidence in order to establish if there are or there aren't reasons for sending someone to judgment [art. 3 para.1) letter a)

The function for disposing over the rights and the fundamental freedoms of the individual during the criminal prosecution, [art. 3 para. 1), letter b)] exercised according to art. 53 The New Code of Cr. Pr. by a new judicial body, the judge of rights and freedoms, which has the authority: to solve, during the criminal prosecution, the petitions, the proposals, the complaints, the appeals or any other notifications regarding the preventive measures, assurance measures, safety measures with a temporary character, approval of the perquisitions, the utilization of the methods and special techniques of surveillance or research and other techniques needed for evidence in accordance with the law (which involve restrictions of the constitutional rights).

The function of checking the lawfulness regarding the sending or not sending for trial [art. 3 para.1) letter c)] exercised, according to art. 54 The New Code of Cr. Pr., by a new judicial body, the judge for the preliminary hearing who has the authority to check: the lawfulness of sending someone for trial disposed by the prosecutor, the lawfulness of managing the evidence and of performing the procedural acts by the criminal prosecution bodies and to solve the complaints against the solutions for not sending someone for trial or not prosecuting someone. This new judicial function performed by the judge for the preliminary hearing was conceived to replace with superior protection standards, the institution stipulated by art. 300 from the old Code, that of checking, made by the court, on the first hearing, the lawfulness of the notification act, as well as the institution stipulated by art. 332 para. 1) and 2) from the same old Code through which the court checked and sanctioned, with referral back to the prosecutor for re-establishing the criminal prosecution, the unlawfulness of the criminal prosecution acts under the aspect of authority, the inobservance of the legal dispositions regarding the notification of the court, regarding the presence of the charged individual and the defendant and their assistance made by the defender in cases mentioned by the law. 
The function of judgment which the courts perform, with the peculiarities which derive from the introduction of the elements from the adversarial type trial.

The second part of the text in art. 3 The New C. Of Cr. Pr. introduces the principle governing the exercise of the four functions and which must ensure the impartiality and the objectivity necessary for a fair trial: the principle of the separate exercise of each function. In this regard, the text in art. 3 para. 3) The New Code of Cr. Pr. stipulates that ,when the same criminal trial is developing, the exercise of a judicial function is incompatible with the exercise of another judicial function."

\section{The criminal prosecution - the first stage of the criminal trial - a function exercised by the prosecutor}

Going back to the function of criminal prosecution which is exercised by the prosecutor, we must highlight the importance and signification of the specification from para. 4) of the text in art. 3 The New Code of Cr. Pr., which stipulates that ,when exercising the function of criminal prosecution, the prosecutor and the criminal prosecution bodies collect the necessary evidences in order to establish, if there are or there aren't reasons for sending someone for trial."

This specification is quite relevant because: when explaining the stipulations, art. 3 para. 1) letter a) is in accordance with the text of art. 285 The New Code of Cr. Pr. which stipulates that the criminal prosecution has as objective to collect the necessary evidences regarding the existence of criminal offences, identification of people who committed an offence and establishing their criminal liabilities, in order to ascertain if there is or there isn't the case to dispose their sending for trial. From the economy of these texts, in correlation with the texts in art. 55 para. 1) letter a), b), c) and para. 3) letter a), b), c) as well as art. 56 The New Code of Cr. Pr. and the texts governing the functional authority of the court during the judging stage, the following can be highlighted:

- the functional authority of the prosecutor is that of performing the criminal prosecution in cases stipulated by law and to manage and check directly the criminal prosecution activity of the judicial police and of the special criminal prosecution bodies;

- in exercising the criminal prosecution function and of checking the criminal investigations, the prosecutor and the criminal prosecution bodies which he is supervising have the attributions to collect the necessary evidences in order to ascertain if there are reasons for sending or for not sending someone for trial; 
- the role and the aim of the collected evidences during the criminal prosecution is to serve as a reason for sending or not sending someone for trial;

- the new regulation establishes, and it is interpreting, the difference between the functions and the aim of the evidences collected during the criminal prosecution, to serve as a reason for sending someone for trial and the functions and the aim of the evidences managed during the judgment stage, to serve as a reason for pronouncing a judge's decision;

- the new regulation explains, and it is interpreting, by means of reference to the texts of art. 349, art. 351, art. 374 para. 7) The New Code of Cr. Pr., that the evidences collected during the criminal prosecution stage, when they are contested, they can still serve at pronouncing a judge's decision only if and after they have been checked during the criminal prosecution, in public meeting, directly and in a contradictory way;

- by means of interpretation, by reference to the texts in art. 349 para. 2) and art. 374 para. 4) and art. 375 The New Code of Cr. Pr., it ensures that the evidences collected during the criminal prosecution, only by exception, can serve as a reason for pronouncing a judge's decision, within the simplified trial procedure of admitting the charge, stipulated by art. 374 para. 4) and art. 375 The New C. of Cr. Pr.

These observations and specifications ensued from the regulations in the New Code have both a theoretical scientifical importance to differentiate between the role, functions and the aim of the evidences collected during the criminal prosecution and the role, functions and the aim of the evidences operated during the trial stage, as well as a practical importance in order to stop the easiness with which, in a lot of cases, the courts pronounce solutions based only on the evidences within the criminal prosecution stage, without being checked by means of the criminal investigation. We are making these clarifications, highlighting that a judge's decision (of conviction, of exoneration, or of ending the criminal trial, of renouncing to apply the penalty or postponing to apply the penalty) can be based on the evidences collected during the criminal prosecution stage, but only when, after checking them, in public meeting, directly and in a contradictory way, the court will express and sustain with reasons, that the evidences expressing the truth are the ones collected during the criminal prosecution stage.

Following the introduction of this new principle of separating the judicial functions within the criminal trial, the function of criminal prosecution exercised by the prosecutor was simplified and re-analysed, in accordance with the regulations of the European Union states, in order to better meet the request of a more efficient criminal trial. 
Taking into consideration the dynamism of the criminal trial and the fact that the preventive measures have the aim to ensure a good developing of the process activity, it is natural that they will be adapted depending on the fact and legal grounds of the case, ensuring therefore a flexibility of these in relation to certain circumstances connected with the legal case which is taking place and with the individual who had done it (either a suspect or a defendant). Under these situations as well, the law giver assigned the prosecutor with important attributions in order to guarantee the respecting of lawfulness regarding the individual's freedom during the entire criminal trial.

\section{The judgment - the second stage of the criminal trial - the role of the prosecutor and the elements of the adversarial type trial}

The modifications brought regarding the place and the role of the prosecutor during the judgment stage follow the introduction of the elements of the adversarial type trial. Therefore, from the economy of the regulations within the new code, it ensures that the prosecutor, as holder of the criminal action, is the one who must prove the accusation respectively, the fact and the guiltiness imputed by means of the notification act, beyond any reasonable doubt.

The court does not have the exercise of the active role and does not have the task to have the evidence, which is assigned to the prosecutor [art. 363 para. 2)].

As a reflection of this role to prove the accusation, art. 363 para. 1) stipulates expressly the obligatory participation of the prosecutor in all the cases, at the trial, both on the substance and on the remedy at law.

In exercising the active role, the prosecutor is the first to be given the right to ask the operation of evidences [art. 100 para. 2)] and to formulate petitions, to claim exceptions and draw conclusions [art. 363 para. 3)].

A new element characteristic for the adversarial type trial is that the prosecutor, during the criminal investigation may ask and formulate questions directly and not via the president of the judicial panel, as the old Code was stipulating (art. 378 The New Code of Cr. Pr.)

The new regulation stipulates a limitation of the principle for hierarchical subordination of the prosecutor taking part at the trials, consecrating his or her independence in the sense of drawing conclusions in a fair way, according to his private opinions based on the operated evidences. In this regard, art. 363 para. 4) stipulates expressly that, when he appreciates that there are any of the reasons that prevent the exercise of the criminal action, the prosecutor draws, as it is the case, conclusions for exoneration or ending of the criminal trial. 
The Place and the Role of the Prosecutor in the Criminal Trial according to (...)

Dănuţ NEACŞU, Luminița SIMA

\section{The extraordinary legal remedies and the role of the prosecutor according to the new modifications}

There are also important novelties referring to the role of the prosecutor regarding the extraordinary legal remedies. Thus, a first new element refers to the fact that the prosecutor can formulate a petition for cancellation, both regarding the legal side and the civil side, but only in the favour of the defendant [art. 436 para. 1) letter a) The New C. of Cr. Pr]. In this regard, art. 434, the last paragraph The New $\mathrm{C}$ of Cr. Pr., stipulates that the action for cancellation, exercised by the prosecutor against the decisions through which the exoneration of the defendant was disposed, cannot have as an aim to obtain his or her conviction by the court performing the action for cancellation. The prosecutor can formulate a petition for cancellation both with regards to the legal side or to the civil side of the case.

In the event that the action for cancellation analysed by the council chamber at The High Court of Cassation and Justice is accepted in principle, and the case is sent in order to judge the action for cancellation, the participation of the prosecutor to judgment is obligatory. The prosecutor may ask, from the office, the review, but only with regards to the criminal side of the irrevocable decision [art. 455 para. 2)].

Another new element is that, if upon the retrial of the case, after its admitting in principle, the court notices that the situation in fact cannot be established directly or that it could be performed in court only with a long delay, disposes the performing of the necessary investigations made by the prosecutor during an interval which cannot exceed 3 months. The prosecutor is obliged to perform the investigations and to pass the entire stuff to the competent court [art. 461 para. 3) and 4) The New C. of Cr. Pr.].

\section{Conclusions}

The New Code of Criminal Procedure has as an essential aim the creation of a modern legislative framework within the legal matters area, which should respond entirely to the imperatives necessary for a modern justice to function, adapted to the social expectations, as well as to the necessity for increasing the quality of this public service. The dispositions of the Code of Criminal Procedure try to respond to actual demands, like expediting the time necessary for the legal procedures, their simplification and the creation of a unitary jurisprudence, in accordance with the jurisprudence of The European Court of Human Rights .

The novelties regarding the place and the role of the prosecutor within the legal trial are in compliance with the European Union Directives regarding 
the rights and the fundamental freedoms of the individual. Therefore, the Public Ministry representatives accomplish the lawfulness principle by exercising the actions in justice necessary for defending the public or the personal interest, whenever the rights and the individual freedoms are violated.

By introducing some new institutions within the New Code of Criminal Procedure, through the essential modifications regarding the place and the role of the prosecutor within the criminal trial, these were not conceived as original solutions to old problems, but compared with the legal existing solutions which proved to be viable in practice, instead a corresponding modification for all the solutions was expected, solutions which generated difficulties and the introduction of new solutions, based on positive comparative experiences or guided towards the expected favourable effects, all following the study of the doctrine for the criminal proceedings law within the internal system and the European ones.

\section{REFERENCES}

The Romanian Constitution modified and completed by Law no. 429/ 2003, published in The Romanian Official Monitor, Part I, no. 758 from the $29^{\text {th }}$ of October 2003, republished by the Legislative Council, under art. 152 from the Constitution, with updates of the naming and giving the texts another numbering (art. 152 became, under republished form, art. 156).

The Convention for defending the human rights and the fundamental freedoms, concluded in Rome on the $4^{\text {th }}$ of November 1950 was ratified through the Law no. 30/ 1994 regarding the ratification of the Convention for defending the human rights and the fundamental freedoms and of the additional protocols for this convention published in the Official Monitor no. 135 from the $31^{\text {st }}$ of May 1994.

Law no. 135/2010 regarding the New Code of Criminal Procedure, published in the Official Monitor no. 486 from the $15^{\text {th }}$ of July 2010, in force from the $1^{\text {st }}$ of February 2014, updated through: OUG no. 3/2014- for taking some implementation measures necessary for applying the Law no. 135/ 2010 regarding the Code of Criminal Procedure and for the implementation of other laws, The Official Monitor 98/2014; Law no. 255/2013 - for implementing Law no. 135/2010 regarding The Code of Criminal Procedure and for the modification and completion of some laws which include criminal procedure dispositions, The Official Monitor 515/ 2013. 